\title{
Studies on the Determination of Compressive Strengths of Different Grades of Rice Husk Ash-An Ecofriendly Concrete
}

\author{
Patnaikuni Chandan Kumar, Nutulapati V. S. Venugopal, Palli Malleswara Rao \\ Department of Civil Engineering, GITAM University, Visakhapatnam, India. \\ Email: Venu7000@gmail.com
}

Received January $16^{\text {th }}, 2013$; revised February $20^{\text {th }}, 2013$; accepted April $6^{\text {th }}, 2013$

Copyright (C) 2013 Patnaikuni Chandan Kumar et al. This is an open access article distributed under the Creative Commons Attribution License, which permits unrestricted use, distribution, and reproduction in any medium, provided the original work is properly cited.

\begin{abstract}
Rice Husk Ash (RHA) Concrete is an eco friendly concrete and has evolved as an innovative technology, capable of achieving the status of being an outstanding advancement in the sphere of concrete technology. The utilization of Rice Husk Ash (RHA) will reduce the dumping of rice husk as well as reduce the construction cost. In this communication investigations for the determination of residual compressive strength of M30 \& 40 grades of RHA concretes exposed at different temperatures were carried. Almost all specimens of M30 \& 40 grades of RHA concrete and normal concrete exhibited zero strength at a temperature of $1000^{\circ} \mathrm{C}$. It shows that concrete cannot withstand a temperature of $1000^{\circ} \mathrm{C}$ and above. It was also concluded that compressive strength of RHA concrete was higher at temperature below $500^{\circ} \mathrm{C}$ and decreases above $500^{\circ} \mathrm{C}$.
\end{abstract}

Keywords: Rice Husk Ash; Compressive Strength; Burning

\section{Introduction}

Concrete is a composite construction material composed primarily of aggregate, cement, and water. Concrete has relatively high compressive strength, but much lower tensile strength. For this reason it is usually reinforced with materials that are strong in tension (often steel). Concrete can be damaged by many processes, such as the freezing of trapped water. Compressive strength results are primarily used to determine that the concrete mixture as delivered meets the requirement of the specified strength in the job. The increasing production, utilization and demand of cement pose a severe threat to the environment and ecology. India is the second largest producer of cement in the world. Also, the production of one tonne of Portland cement requires 1.55 to 1.6 tonne of raw material. These materials are primarily of good quality limestone and clay [1]. Rice husk is unusually high in ash compared to other biomass fuels - close to $20 \%$. The ash is $92 \%$ to $95 \%$ silica $\left(\mathrm{SiO}_{2}\right)$, highly porous and lightweight, with a very high external surface area. Its absorbent and insulating properties are useful to many Industrial applications, and the ash has been the subject of many research studies. Rice Husk Ash has many applica- tions due to its various properties. Mauro M. Tashima et al. [2] studied how different grades of RHA concrete can influence its physico-mechanical properties was studied. Many researchers [3-6] explained the several key properties of high strength concrete using Rice Husk Ashes (RHAs). RHAs obtained from two sources: India and Vietnam were used with various contents to partially replace for cement binder in high strength concrete. Key properties of concrete, including: slump, density, compressive strength, water and chloride permeability resistances, were investigated in comparison between samples without using RHA and samples using two types of RHAs. Muhammad Shoaib Ismail et al. [7] studied the effect of Rice Husk Ash (RHA) as a 10\% - 30\% replacement of cement on the strength of HSC was studied. Moayad N. Al-Khalaf et al. [8] showed that Rice Husk Ash was prepared as a pozzolana by a special process such that the final product conformed to engineering requirements in terms of physical and chemical properties, and the silica remained in an amorphous form with a minor amount of unburnt carbon. D. Bui, J. Hu, et al. [9] (2005) showed that Rice Husk Ash (RHA) has been used as a highly reactive pozzolanic material to improve the microstructure of the interfacial transition zone (ITZ) be- 
tween the cement paste and the aggregate in high-performance concrete. The development of Mechanical properties up to 180 days of self compacting and ordinary concretes with rice-husk ash (RHA) Two different replacement percentages of cement by RHA $10 \%$, and $20 \%$, and two different water/cementicious material ratios $(0.40$ and 0.35$)$ and it is concluded that $20 \%$ RHA concrete provides a positive effect on the Mechanical properties at age after 60 . All the earlier studies are on normal, fly ash and silica fume concretes. The studies on RHA concretes are very few. The studies of RHA concretes are mostly considering the percentage of replacements of $0,5,10,15,20$. The author reported in this communication investigations of residual compressive strength of different grades such as M30, M40 of RHA concretes exposed to $27^{\circ} \mathrm{C}$ (room temperature), $300^{\circ} \mathrm{C}$, $500^{\circ} \mathrm{C}, 700^{\circ} \mathrm{C}, 900^{\circ} \mathrm{C}$ and $1000^{\circ} \mathrm{C}$.

\section{Materials and Methods}

\subsection{Cement}

Cement used in the experimental work is PORTLAND POZZOLONA CEMENT Conforming to IS: 1489 (Part1)1991.

\subsection{Rice Husk Ash}

Rice Husk Ash used in the present experimental study was obtained from Orissa, INDIA.

\subsection{Fine Aggregate}

Fine aggregate (sand) used in this experimental work confirms to zone III as per the specifications of IS 383: 1970 [10].

\subsection{Coarse Aggregate}

Crushed granite of $20 \mathrm{~mm}$ maximum size has been used as coarse aggregate. The sieve analysis of combined aggregates conforms to the specifications of IS 383: 1970 [10] for graded aggregates. The specific gravity of coarse aggregate is 2.70 .

\subsection{Mix Proportion}

Three grades of concrete M30, M40 were used in this study. Cement by weight was replaced by RHA in the range of $0 \%, 5 \%, 7.5 \%, 10 \%, 12.5 \%, 15 \%, 20 \%$, for all three grades of concrete, to estimate the residual strengths of RHA concretes at different temperatures varying from $27^{\circ} \mathrm{C}$ to $1000^{\circ} \mathrm{C}$ for different durations of heating. All samples were water cured for 28 days to estimate/asses all parameters in the entire study. The mix proportions arrived for $\mathrm{M} 30$ \& 40 grades are given in Tables 1 and 2.

Table 1. Mix proportion of M30 grade RHA concretes for different replacements.

\begin{tabular}{ccccccc}
\hline S. No & RHA replacement & Cement & Fine aggregate & Coarse aggregate & W/b ratio & S.P. dosage in ml. \\
\hline 1 & $0 \%$ & 1 & 1.4 & 2.80 & 0.45 & - \\
2 & $5 \%$ & 0.95 & 1.4 & 2.80 & 0.45 & 12 \\
3 & $7.5 \%$ & 0.925 & 1.4 & 2.80 & 0.45 & 13 \\
4 & $10 \%$ & 0.9 & 1.4 & 2.80 & 0.45 & 14 \\
5 & $12.5 \%$ & 0.875 & 1.4 & 2.80 & 0.45 & 15 \\
7 & $15 \%$ & 0.85 & 1.4 & 2.80 & 0.45 & 17 \\
\hline
\end{tabular}

Table 2. Mix proportion of M40 grade RHA concretes for different replacements.

\begin{tabular}{ccccccc}
\hline S. No & RHA replacement & Cement & Fine aggregate & Coarse aggregate & W/b ratio & S.P. dosage in ml. \\
\hline 1 & $0 \%$ & 1 & 1.6 & 2.6 & 0.4 & - \\
2 & $5 \%$ & 0.95 & 1.6 & 2.6 & 0.4 & 13 \\
3 & $7.5 \%$ & 0.925 & 1.6 & 2.6 & 0.4 & 14 \\
4 & $10 \%$ & 0.9 & 1.6 & 2.6 & 0.4 & 15 \\
5 & $12.5 \%$ & 0.875 & 1.6 & 2.6 & 0.4 & 17 \\
7 & $15 \%$ & 0.85 & 1.6 & 2.6 & 0.4 & 19 \\
\hline
\end{tabular}




\section{Method}

All ingredients were placed in the mixer except water and mixed in the dry condition. Initially $80 \%$ of water is added and mixed for 75 seconds. The remaining Quantity of water is then added to the concrete mix replaced with RHA in different percentages by weight of cement and mixed for 45 seconds. Super plasticizer dosages have been added to maintain the workability of $75 \mathrm{~mm}$ for all the mixes mentioned above in Table 3 . Specimens were cast in $100 \times 100 \times 100 \mathrm{~mm}$ cube moulds. The specimens were compacted using table vibrator. For all specimens a constant compaction time of 50 seconds was adopted. All Samples were water cured for 28 days before carrying out all investigations. A total of 150 samples were cast and tested in the laboratory to study the sea water effect and rate of water absorption of Rice Husk Ash Concretes.

\section{Testing of Specimens for Compressive Strength}

Test specimens of size $100 \mathrm{~mm} \times 100 \mathrm{~mm} \times 100 \mathrm{~mm}$ were exposed to sea water. The specimens are placed in the compression testing machine in such way that the centre of steel plate of the compression testing machine will pass through the centre of the specimen. The load was applied gradually at a rate of $5 \mathrm{KN} /$ minute until the specimen showed the first crack. The maximum load applied to the specimen was recorded from the compressive strength testing machine. The compressive strength is then calculated by dividing the maximum load carried by the specimen by the actual cross sectional area. The real dimensions of the specimen were taken into account while calculating the cross sectional area. For each variation, average of three specimens was taken as the compressive strength provided the individual variation was not more than $15 \%$ on the average.

\section{Results and Discussions}

The compressive strengths for different replacements of M30 \& 40 grade concretes are shown in Table 4 . The specifications, physical, and chemical properties of the Rice Husk Ash are given in Tables 3, 5 and 6.

Table 3. Specifications of Rice Husk Ash.

\begin{tabular}{cc} 
Silica & $90 \%$ minimum \\
Humidity & $2 \%$ maximum \\
Mean Particle Size & 25 microns \\
Color & Grey \\
Loss on Ignition at $800^{\circ} \mathrm{C}$ & $4 \%$ maximum \\
\hline
\end{tabular}

Table 4. Compressive strengths for different replacements of $\mathrm{M} 30$ \& 40 grade concretes.

\begin{tabular}{cccccc}
\hline $\begin{array}{c}\text { Replacement } \\
\rightarrow \\
\text { Age } \\
\downarrow\end{array}$ & $0 \%$ & $5 \%$ & $7.50 \%$ & $10 \%$ & $12.50 \%$ \\
\hline 28 & 30,28 & $31.4,31.2$ & $32.33,33.74$ & 32,33 & $31.5,32$ \\
56 & 30,26 & $31.33,31.1132 .02,32.18$ & 30,28 & $29.8,30$ \\
90 & 31,25 & $30.8,30.2$ & $31.6,31.89$ & $29.1,26.7$ & $28.2,27.84$ \\
\hline
\end{tabular}

Table 5. Physical properties of Rice Husk Ash.

\begin{tabular}{cc}
\hline Physical State & Solid-Non Hazardous \\
Appearance & Very fine powder \\
Particle Size & 25 microns-mean \\
Color & Grey \\
Odour & Odourless \\
Specific Gravity & 2.3 \\
\hline
\end{tabular}

Table 6. Chemical properties of Rice Husk Ash.

\begin{tabular}{cc}
\hline $\mathrm{SiO}_{2}$ & $93.80 \%$ \\
$\mathbf{A l}_{2} \mathbf{O}_{3}$ & $0.74 \%$ \\
$\mathrm{Fe}_{2} \mathbf{O}_{3}$ & $0.30 \%$ \\
$\mathrm{TiO}_{2}$ & $0.10 \%$ \\
$\mathbf{C a O}$ & $0.89 \%$ \\
$\mathbf{M g O}$ & $0.32 \%$ \\
$\mathbf{N a}_{2} \mathbf{O}$ & $0.28 \%$ \\
$\mathbf{K}_{2} \mathbf{O}$ & $0.12 \%$ \\
$\mathbf{L o i}$ & $3.37 \%$ \\
\hline
\end{tabular}

Comparative study on Rice Husk Ash concrete with various replacement percentages of RHA showed that, a replacement level of 7.5\% RHA in concrete performs and shows better compressive strength than other replacements. Hence, $7.5 \%$ RHA replacement may be recommended as the optimum replacement level. Concrete cubes of size $100 \times 100 \times 100 \mathrm{~mm}$ were cast and were tested for compressive strength and the results were presented in Table 5 for $0 \%, 5 \%, 7.5 \%, 10 \%$ and $12.5 \%$ of RHA replacement of cement for M30 \& 40 grades of concrete at room temperature, after 28 days of water curing. It was concluded that for M30 and M40 grades of RHA concretes, the strengths show a decreasing trend with increase in the duration of heating. This may be due to the breakage of bond between the molecules of concrete matrix due to sustained heating. Hence RHA Concrete may be used in place of normal concrete due to its suitable performance for construction needs. 


\section{REFERENCES}

[1] IS 383, "Bereau of Indian Standards," Manak Bhavan, New Delhi, 1970.

[2] M. M. Tashima, C. A. R. Silva, J. L. Akasaki and M. B. Barbosa, "Influence of Rice Husk Ash in Mechanical Characteristics of Concrete," Supplementary Cementing Materials, 1985, pp. 780-790.

[3] D. Van Dong, P. D. Huu and N. N. Lan, "Effect of Rice Husk Ash on Properties of High Strength Concrete," The 3rd ACF International Conference, 2008, pp. 442-449.

[4] A. N. Givi, S. A. Rashid, F. Nora, A. Aziz, M. Amran and M. Salleh, "Contribution of Rice Husk Ash to the Properties of Mortar and Concrete: A Review," Journal of American Science, Vol. 6, No. 3, 2010, pp. 157-165.

[5] M. H Zhang, R. Lastra and V. M. Malhotra, "Rice-Husk Ash Paste and Concrete: Some Aspects of Hydration and the Microstructure of the Interfacial Zone between the Aggregate and Paste," Cement and Concrete Research, Vol. 26, No. 6, 1996, pp. 963-977.

doi:10.1016/0008-8846(96)00061-0
[6] R. Jauvertgue, F. Rendell, S. Tamba and I. K. Cisse, "Properties of Cement-Rice Husk Mixture," Construction and Building Materials, Vol. 17, No. 4, 2003, pp. 239-243.

[7] M. S. Ismail and A. M. Waliuddin, "Effect of Rice Husk Ash on High Strength Concrete," Construction and Building Materials, Vol. 10, No. 7, 1996, pp. 521-526. doi:10.1016/0950-0618(96)00010-4

[8] M. N. Al-Khalaf and H. A. Yousift, "Use of Rice Husk Ash in Concrete," The International Journal of Cement Composites and Lightweight Concrete, Vol. 6, No. 4, 1984, pp. 241-248. doi:10.1016/0262-5075(84)90019-8

[9] D. D. Bui, J. Hu and P. Stroeven, "Particle Size Effect on the Strength of Rice Husk Ash Blended Gap-Graded Portland Cement Concrete," Cement \& Concrete Composites, Vol. 27, No. 3, 2005, pp. 357-366. doi:10.1016/j.cemconcomp.2004.05.002

[10] IS 383, "Bereau of Indian Standards," Manak Bhavan, New Delhi, 1970. 